Tersedia online di http://ejournal-balitbang.kkp.go.id/index.php/jp
e-mail:jurnalpari@gmail.com
Jurnal Pari
Volume 2 Nomor 1 Juli 2016
p-ISSN : 2502-0730
e-ISSN : 2549-0133

\title{
PRODUKTIVITAS PENELITI PUSAT PENELITIAN DAN PENGEMBANGAN PERIKANAN BUDIDAYA : SUATU KAJIAN PADA JURNAL RISET AKUAKULTUR
}

\section{PRODUCTIVITY SCIENTIST OF RESEARCH CENTER AND DEVELOPMENT OF AQUACULTURE FISHERIES : STUDY ON JOURNAL OF AQUACULTURE RESEARCH}

\author{
Syarianah \\ Balai Penelitian dan Pengembangan Budidaya Air Payau \\ Diterima tanggal : 26 Mei 2016 Diterima setelah perbaikan : 21 Juni 2016 \\ disetujui terbit : 8 Juli 2016
}

\section{ABSTRAK}

Untuk mengetahui produktivitas peneliti lingkup Pusat Penelitian dan Pengembangan Perikanan Budidaya (P4B), dilakukan kajian terhadap Jurnal Riset Akuakultur selama 5 tahun (2007-2011) yang diterbitkan oleh Pusat Penelitian dan Pengembangan Perikanan Budidaya.

Metode menggunakan analisis dokumen. Hasil kajian menunjukkan bahwa dari 225 artikel yang dimuat di jurnal riset akuakultur sebagian besar berasal dari lingkup P4B yaitu $197(88,44 \%)$ artikel. 2 artikel $(0.89 \%)$ dari BBPPPPBP Jakarta, 5 (2.22\%) artikel dari UPT KKP diluar BalitbangKP $2(0.89 \%)$ artikel dari UPT diluar KKP, dan 19 (8.44) artikel berasal dari perguruan tinggi di Indonesia. Produktivitas tertinggi lingkup P4B adalah P4B dan BPPBAT Bogor yaitu masing-masing 0.30 per tahun, kemudian BPPBAP Maros 0.26 per tahun, BBPPBL Gondol 0.13 per tahun, BPPTBPAT Sukamandi 0.10 per tahun dan BPPBIH Depok 0.06 per tahun. Penulis pertama yang memberi kontribusi lebih dari satu artikel terbanyak berasal dari BPPBAP Maros yaitu 17 (30.36\%), BBPPBL Gondol $12(21,43 \%)$, BPPBAT Bogor $10(17.87 \%)$, P4B Jakarta $7(15.63 \%)$, dan BPPBIH Depok $5(8.93 \%)$. Artikel dengan kolaborasi tiga penulis merupakan yang terbanyak, yaitu 82 artikel $(36.44 \%)$, disusul kolaborasi dua penulis yaitu 53 artikel (23.56\%) kemudian kolaborasi empat sebanyak 51 artikel (22.67\%). Kolaborasi penulis lima sebanyak 20 artikel (8.89\%), kolaborasi enam penulis. 4 artikel (1.78\%), kolaborasi tujuh, delapan dan sembilan masing-masing 1 artikel $(0.44 \%)$.

Kata Kunci : Produktivitas, Penelitian, Artikel, Jurnal Riset Akuakultur

\section{ABSTRACT}

To understand the productivity of researchers working in the Research and Development Center of Aquaculture, a 5 year study on the Aquaculture Research Journal has been conducted from 2007 - 2011, which has been published by the Research and Development Center of Aquaculture.

The method used was document analysis. Result of the study shows that most of the 225 articles of aquaculture research journal come from the Research and Development Center of Aquaculture which amounts to 197 (88,44\%) articles. 2 articles are from BBPPPPBP Jakarta, 5 (2.22\%) articles are from other units of Ministry Marine Affairs (MMAF) outside Agency Research and Development Marine and Fisheries. 2 (0.89\%) articles come from unit outside MMAF. And 19 (8.44\%) article comes from University in Indonesia. By the smaller units, the highest productivity within the Research and Development Center of Aquaculture is Puslitbang perikanan and BPPBAT Bogor which is 0.3 each year, and then BPPBAP Maros 0.26 each year, BBPPBL Gondol 0.13 each year, BPPTBPAT Sukamandi 0.1 each year and BPPPBIH Depok 0.06 each year. First author who give contribution more than one article mostly come from BPPBAP Maros which is 17(30.36\%) BBPPBL Gondol 12 (21.43\%), BPPBAT Bogor 10 (17.87\%), Puslitbang Perikanan Budidaya 7 (15.63\%) and BPPBIH Depok 5 (8,93\%). Articles by collaboration of 3 writers is the most in numbers which are 82 articles (36.44\%) and then Collaboration result from two writers are 53 articles (23.56\%) and then Colaboration of four writers are 51 articles(22,67\%). Colaboration five writers are 20 articles (8.89\%), Collaboration six writers 4 articles (1.78\%), seven, eight, and nine Collaboration writers each 1 article (0,44\%).

Keywords : Productivity, Research, Articles, Aquaculture Research Journal

Korespondensi Penulis :

Jl. Makmur Dg. Sitakka No. 129, Maros 90512, Sulawesi Selatan

Email : syariana64@yahoo.co.id 


\section{PENDAHULUAN}

"Peneliti yakni orang-orang yang melakukan kegiatan penelitian yang tidak terbatas pada jabatan fungsional meliputi para akademisi dan peneliti di litbang kementerian maupun LPNK (Lakitan, 2012). Tugas pokok peneliti adalah melakukan penelitian dan pengembangan ilmu pengetahuan dan teknologi (Kep. Bersama Ka LIPI dan Ka BKN Nomor 3719/D/2004 dan Nomor 60 Tahun 2004). Peneliti dalam pengertian luas dapat merujuk pada setiap orang yang melakukan aktivitas menggunakan sistem tertentu dalam memperoleh pengetahuan atau individu yang melakukan sejumlah praktik-praktik dimana secara tradisional dapat dikaitkan dengan kegiatan pendidikan, pemikiran, atau filosofis. Secara khusus, istilah peneliti dikaitkan pada individuindividu yang melakukan penelitian (meneliti) dengan menggunakan metode ilmiah. Seorang peneliti, bisa jadi adalah seorang ahli pada satu bidang atau lebih dalam ilmu pengetahuan. Peneliti sebagai komunitas pencipta dan pengguna pengetahuan ilmiah mempunyai peran penting dalam penciptaan ilmu melalui penelitian atau pengkajian ilmiah. Untuk itu peneliti dituntut memiliki pengetahuan, alat, dan fasilitas yang memadai agar dapat mencapai hasil yang dapat dipertanggungjawabkan secara ilmiah. Dukungan untuk mengembangkan ilmu pengetahuan juga menjadi dasar bagi peneliti bidang kelautan dan perikanan untuk dapat melakukan kegiatan penelitian, pengkajian, percobaan, dan penemuan baru secara individual maupun berkelompok dan bekerja sama.

Pusat Penelitian dan Pengembangan Perikanan Budidaya (P4B) merupakan salah satu pusat penelitian dan pengembangan yang ada di lingkup Badan Penelitian dan Pengembangan Kelautan Perikanan (BalitbangKP), Kementerian Kelautan dan Perikanan yang mempunyai visi menjadi Pusat Penelitian dan Pengembangan yang handal dan pemandu yang terpercaya bagi pengembangan IPTEK perikanan budidaya, dengan misi : Menguasai, mengembangkan, dan menerapkan IPTEK perikanan budidaya, meningkatkan pelayanan jasa informasi IPTEK perikanan budidaya, dan mengembangkan profesionalisme kelembagaan dan sumber daya riset perikanan budidaya. Salah satu bentuk evaluasi yang dapat dilakukan untuk mengetahui kontribusi suatu lembaga dalam pelaksanaan kegiatan penelitian yaitu dengan mengukur produktivitas peneliti melalui publikasi ilmiah. Produktivitas publikasi atau disebut juga research output atau produktivitas penelitian merupakan salah satu indikator research performance atau kinerja penelitian. Seorang peneliti dikatakan memiliki produktivitas tinggi apabila peneliti banyak menghasilkan karya tulis ilmiah dan dipublikasikan dalam jurnal ilmiah (Sutardji, 2012).

Produktivitas menurut Nasution (2002) dalam Salinding, (2011) menjelaskan bahwa: "Produktivitas merupakan rasio antara hasil kegiatan (output) dan segala pengorbanan (biaya) untuk mewujudkan hasil (input). Dimana peningkatan produktivitas akan meningkatkan pendapatan karyawan yang akan menambah daya beli masyarakat". Dengan kata lain, produktivitas merupakan konsep rasio, yaitu rasio output terhadap input menjadi lebih besar. Dengan demikian, nilai rasio output dibuat menjadi lebih besar melalui peningkatan salah satu output pada tingkat input yang konstan, mengurangi pengunaan input, atau kombinasi keduanya. Aziz dan Komarudin (1991) dalam Wahid, N. (2010) mengatakan bahwa untuk mengetahui tingkat produktivitas peneliti, ada beberapa unsur yang dinilai oleh Tim Penilai Jabatan Peneliti yang ditetapkan oleh pemerintah dibagi 2 kelompok yaitu:

1. Unsur Utama, yaitu pendidikan, karya tulis ilmiah, dan pemacuan teknologi

2. Unsur Penunjang, yaitu pemasyarakatan ilmu dan teknologi, keikutsertaan dalam kegiatan ilmiah, pembinaan kader ilmiah, penghargaan ilmiah.

Sedangkan Menurut Lakitan, (2012) mengemukakan, bahwa salah satu komponen produktivitas penelitian yaitu kuantitas yang dihasilkan peneliti yang berbentuk jumlah publikasi ilmiah. Publikasi ini bisa dalam publikasi internasional/ global dan publikasi terbatas dalam bentuk hardcopy. Dan yang bertanggung jawab terhadap publikasi tersebut 
adalah peneliti sendiri. "Kebanyakan peneliti kita belum melihat hasil dari penelitian tersebut kepada masyarakat yang lebih luas sebagai bentuk kewajiban kepada publik. Padahal indikator itu menjadi sangat penting sebagai salah satu bentuk pertanggungjawaban para peneliti".

Produktivitas penelitian dapat diukur kuantitas maupun kualitasnya (Zainab 2000). Pengukuran kuantitas produktivitas penelitian yang dilakukan Blackburn et al. (1978) adalah dengan menghitung total artikel yang ditulis oleh 1.216 akademisi dariperguruan tinggi dan 7.484 staf universitas di Amerika Serikat dengan menggunakan kuesioner. Braun et al. (1990) mengkaji produktivitas publikasi pengarang di 10 negara dengan menggunakan data dari pangkalan data Science Citation Index (SCl) periode1981-1985. Budd (1995) meneliti produktivitas publikasi para akademisi perguruan tinggi yang juga merupakan anggota Association of Research Libraries, yang diambil dari tiga indeks sitasi SCI. Menghitung publikasi peneliti tidak hanya bermanfaat untuk menentukan produktivitas penelitian, tetapi juga untuk mengkaji trend pada suatu disiplin ilmu. Pengkajian produktivitas penelitian juga dilakukan oleh Diodato (1994) dengan menghitung jumlah artikel, buku, dan makalah konferensi dari seseorang atau kelompok yang dihasilkan dalam satu periode Penelitian.

Sampai saat ini belum ada evaluasi mengenai produktivitas penelitian atau publikasi di bidang kelautan dan perikanan. Pengkajian ini bertujuan untuk mengetahui produktivitas penelitian lingkup P4B melalui Jurnal Riset Akuakultur. Hasil pengkajian diharapkan dapat memberi gambaran tentang produktivitas penelitian di Pusat Penelitian dan Pengembangan Perikanan Budidaya. Selain itu, diharapkan dapat bermanfaat sebagai masukan dalam pengambilan kebijakan penerbitan publikasi, serta perencanaan penelitian, termasuk penyediaan sumber informasi mutakhir di bidang perikanan.

\section{Bahan dan Metode}

Kajian dilakukan terhadap jurnal riset akuakultur yang dipublikasikan selama 5 tahun (2007-2011) yaitu Volume 2-6 Nomor 1-3, yang diterbitkan oleh Pusat Penelitian dan Pengembangan Perikanan Budidaya. Kajian dilakukan melalaui pendekatan analisis dokumen untuk mengetahui produktivitas peneliti di lingkup P4B. Analisis dokumen dilakukan dengan cara pemeriksaan dan pencatatan secara sistematis terhadap unit analisis dan variabel-variabel penelitian yang digunakan. Variabel variabel tersebut diambil dari masing-masing artikel dalam jurnal tersebut diinventarisasi berdasarkan jumlah artikel, judul, penulis, institusi, tahun, dan penerbit. Data yang terkumpul kemudian dianalisis yang meliputi:

1. Sebaran artikel yang diterbitkan selama lima tahun berdasarkan unit kerja;

2. Produktivitas penelitian Jurnal Riset Akuakultur selama lima tahun;

3. Jumlah peneliti yang memberi konstribusi artikel lebig dari satu artikel; dan

4. Tingkat kolaborasi penulis yang dihitung dengan rumus Subramanyan (1983), yaitu :

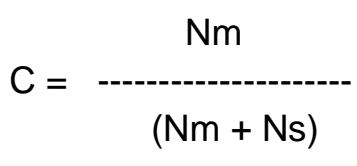

$\mathrm{C}=$ tingkat kolaborasi penulis dalam suatu disiplin ilmu (nilai $0-1$ )

$\mathrm{Nm}$ = jumlah penulis ganda (lebih dari satu)

Ns = jumlah penulis tunggal

\section{Hasil dan Pembahasan}

a. Sebaran artikel menurut unit kerja

Dalam kurun waktu lima tahun terakhir (2007-2011), Jurnal Riset Akuakultur memuat 225 artikel yang berasal dari 21 unit kerja, 7 unit kerja berasal dari lingkup BalitbangKP, 3 unit kerja dari luar BalitbangKP, 1 unit kerja dari luar Kementerian Kelautan dan Perikanan (KKP), 1 unit kerja swasta, dan 9 dari Perguruan Tinggi di Indonesia (Tabel 1). Dari 7 unit kerja BalitbangKP 6 unit kerja berasal dari Pusat Penelitian dan Pengembangan Perikanan Budidaya (P4B) dan hanya 1 unit kerja diluar P4B yaitu Balai Besar Penelitian \& Pengembangan Pengolahan Produk \& Bioteknologi Perikanan. 
Dari 225 artikel yang dimuat di jurnal riset akuakultur sebagian besar artikel berasal dari lingkup P4B yaitu 197 (88.44\%) artikel. Sisanya 2 artikel $(0.89 \%)$ dari Balai Besar Penelitian \& Pengembangan Pengolahan Produk \& Bioteknologi Perikanan, 5 (2.22\%) artikel dari UPT KKP duar BalitbangKP, 2 (0.89\%) artikel dari UPT diluar KKP, dan 19 (8.44) artikel berasal dari perguruan tinggi di Indonesia.

Dari 197 artikel yang berasal dari lingkup P4B , Balai Penelitian dan Pengembangan Budidaya Air Payau Maros merupakan unit kerja b. Produktivitas Peneliti

Produktivitas peneliti didefinisikan sebagai perbandingan antara hasil yang dicapai (jumlah artikel) dengan seluruh sumber daya yang digunakan (jumlah peneliti). Produktivitas peneliti lingkup P4B dapat dilihat pada jumlah artikel yang diterbitkan dalam Jurnal Riset Akuakultur tahun 2007-2011 (Tabel 2). Dengan jumlah peneliti 203 orang peneliti, selama lima tahun menghasilkan 197 artikel. Ini berarti

Tabel 1. Sebaran Artikel pada Jurnal Riset Akuakultur 2007-2011 menurut Unit Kerja

\begin{tabular}{clcc}
\hline No & \multicolumn{1}{c}{ Unit Kerja } & $\begin{array}{c}\text { Jumlah } \\
\text { Artikel }\end{array}$ & Persentase \\
\hline 1 & $\begin{array}{l}\text { Pusat Penelitian \& Pengembangan Perikanan Budidaya } \\
\text { (P4B) Jakarta }\end{array}$ & 30 & 13.33 \\
2 & $\begin{array}{l}\text { Balai Besar Penelitian \& Pengembangan Budidaya Laut } \\
\text { (BBPPBL) Gondol }\end{array}$ & 32 & 14.22 \\
3 & $\begin{array}{l}\text { Balai Penelitian \& Pengembangan Budidaya Air Tawar } \\
\text { (BPPBAT) Bogor }\end{array}$ & 38 & 16.90 \\
4 & $\begin{array}{l}\text { Balai Penelitian \& Pengembangan Budidaya Air Payau } \\
\text { (BPPBAP) Maros }\end{array}$ & 76 & 33.78 \\
5 & $\begin{array}{l}\text { Balai Penelitian Pemuliaan dan Teknologi Budidaya } \\
\text { Perikanan Air Tawar (BPPTBPAT) Sukamadi }\end{array}$ & 12 & 5.33 \\
6 & $\begin{array}{l}\text { Balai Penelitian \& Pengembangan Budidaya Ikan Hias } \\
\text { (BPPBIH) Depok }\end{array}$ & 9 & 4.00 \\
7 & $\begin{array}{l}\text { Balai Besar Penelitian \& Pengembangan Pengolahan } \\
\text { Produk \& Bioteknologi Perikanan (BBPPPPBP) Jakarta }\end{array}$ & 2 & 0.89 \\
8 & UPT KKP diluar Balitbang KP & 5 & 2.22 \\
9 & UPT diluar KKP & 2 & 0.89 \\
10 & Perguruan Tinggi & 19 & 8.44 \\
\hline & Jumlah & 225 & 100 \\
\hline
\end{tabular}

yang memberi kontribusi artikel terbesar, yakni 76 (33.78\%) artikel, disusul Balai Penelitian \& Pengembangan Budidaya Air Tawar Bogor 38 (16.90\%)artikel, kemudian Balai Besar Penelitian \& Pengembangan Budidaya Laut Gondol sebanyak 32 (14.22\%) artikel. Pusat Penelitian dan Pengembangan Perikanan Budidaya Jakarta memberi konstribsi 30 (13.33\%) artikel. Selanjutnya Balai Penelitian Pemuliaan dan Teknologi Budidaya Perikanan Air Tawar Sukamandi memberikan kontribusi artikel sebanyak 12 (5.33\%) artikel dan Balai Penelitian \& Pengembangan Budidaya Ikan Hias Depok memberi kontribusi sebanyak 9 $(4.00 \%)$ artikel. peneliti lingkup P4B hanya menghasilkan artikel primer sebanyak 0.97 atau rata-rata 0.19 artikel/peneliti/tahun.

Produktivitas tertinggi peneliti Lingkup P4B diperoleh dari unit kerja $P 4 B$ sendiri dan BPPBAT Bogor yaitu masing-masing 0.30 per tahun, kemudian BPPBAP Maros 0.26 per tahun, BBPPBL Gondol 0.13 per tahun, BPPTBPAT Sukamandi 0.10 per tahun BPPBIH, dan Depok 0.06 per tahun. Produktivitas peneliti lingkup P4B tersebut di atas masih lebih tinggi dari hasil kajian Sutardji (2011) yang mengatakan bahwa produktivitas artikel primer unit kerja lingkup Puslitbangtan tergolong 
rendah, yaitu rata-rata 0,10 artikel/peneliti/tahun. Namun jika dibanding produktivitas peneliti Balitbang Pertanian tahun 2004 - 2006 masih tergolong rendah yaitu berkisar $0.22-0.93$ atau rata-rata 0.58 artikel per tahun Rufaidah (2010).

Menurut Widiastuti (2012) produktivitas peneliti Indonesia sangat rendah. Dalam 10 sumber informasi, (4) inisiatif, (5) kecerdasan, (6) kreativitas, (7) kemampuan untuk belajar, (8) stimulasi dari pimpinan, (9) kepentingan kenaikan pangkat/kemajuan, (10) orientasi eksternal, dan (11) komitmen pada profesionalisme.

Tabel 2. Produktivitas peneliti pada Jurnal Riset Akuakultur 2007-2011.

\begin{tabular}{|c|c|c|c|c|c|c|c|c|}
\hline \multirow{2}{*}{ Instansi } & \multirow{2}{*}{$\begin{array}{l}\text { Jumlah } \\
\text { Peneliti }\end{array}$} & \multicolumn{5}{|c|}{ Tahun } & \multirow{2}{*}{$\begin{array}{l}\text { Jumlah } \\
\text { Artikel }\end{array}$} & \multirow{2}{*}{$\begin{array}{l}\text { Produktivitas } \\
\text { Per Tahun }\end{array}$} \\
\hline & & 2007 & 2008 & 2009 & 2010 & 2011 & & \\
\hline $\begin{array}{l}\text { Pusat Penelitian \& Pengembangan } \\
\text { Perikanan Budidaya (P4B) Jakarta }\end{array}$ & 20 & 4 & 9 & 7 & 6 & 4 & 30 & 0.30 \\
\hline $\begin{array}{l}\text { Balai Besar Penelitian \& } \\
\text { Pengembangan Budidaya Laut } \\
\text { (BBPPBL) Gondol }\end{array}$ & 48 & 6 & 7 & 6 & 9 & 4 & 32 & 0.13 \\
\hline $\begin{array}{l}\text { Balai Penelitian \& Pengembangan } \\
\text { Budidaya Air Tawar (BPPBAT) Bogor }\end{array}$ & 25 & 10 & 7 & 6 & 9 & 6 & 38 & 0.30 \\
\hline $\begin{array}{l}\text { Balai Penelitian \& Pengembangan } \\
\text { Budidaya Air Payau (BPPBAP) Maros }\end{array}$ & 58 & 17 & 14 & 12 & 12 & 21 & 76 & 0.26 \\
\hline $\begin{array}{l}\text { Balai Penelitian Pemuliaan dan } \\
\text { Teknologi Budidaya Perikanan Air } \\
\text { Tawar (BPPTBPAT) Sukamadi }\end{array}$ & 23 & & 3 & 1 & 3 & 5 & 12 & 0.10 \\
\hline $\begin{array}{l}\text { Balai Penelitian \& Pengembangan } \\
\text { Budidaya Ikan Hias (BPPBIH) Depok }\end{array}$ & 29 & 3 & 1 & 3 & 1 & 1 & 9 & 0.06 \\
\hline Lain-lain & & 5 & 4 & 10 & 5 & 4 & 28 & \\
\hline Jumlah & 203 & 45 & 45 & 45 & 45 & 45 & 197 & 0.19 \\
\hline
\end{tabular}

tahun terakhir, rata-rata dari enam sampai tujuh orang peneliti hanya mampu mempublikasikan satu artikel di jurnal internasional. "Produktivitas peneliti Indonesia menyedihkan. Hal ini karena berdasarkan data sejak 2001-2011, dari enam sampai tujuh peneliti di Indonesia, hanya mampu mempublikasikan satu artikel di jurnal internasional," ungkap Deputi Bidang Kelembagaan IImu Pengetahuan dan Teknologi Kementerian Riset dan Teknologi, Lakitan, (2012). Jika sebelumnya jumlah penelitian karya Indonesia lebih unggul dari Malaysia, saat ini justru sebaliknya. Bahkan jumlah riset peneliti Malaysia yang terpublikasikan dalam jurnal ilmiah meningkat lima kali lipat dibandingkan Indonesia.

Singh dan Babu (1998) dalam Rufaidah (2012) menyarikan beberapa factor yang memengaruhi produktivitas penelitian pada peneliti bidang pertanian di India. Faktor-faktor tersebut yaitu: (1) kegigihan peneliti, (2) kecukupan sumber daya, (3) akses terhadap c. Peneliti yang memberi kontribusi lebih dari satu artikel

Dari 197 artikel yang ditulis oleh peneliti lingkup P4B, sebanyak 141 (71.57\%) artikel merupakan artikel yang ditulis oleh penulis pertama yang berbeda dan 56 (24.43\%) artikel yang tulis oleh beberapa orang penulis pertama yang sama (Tabel 3 ). Dari 56 orang penulis pertama yang memberi kontribusi lebih dari satu artikel pada Jurnal Riset Akuakultur, 17 (30.36\%) artikel berasal dari Balai Penelitian \& Pengembangan Budidaya Air Payau Maros, 12 $(21.43 \%)$ artikel berasal dari Balai Besar Penelitian \& Pengembangan Budidaya Laut Gondol, 10 (17.87\%) artikel dari Balai Penelitian \& Pengembangan Budidaya Air Tawar Bogor, 7 (15.63\%) artikel dari Pusat Penelitian dan Pengembangan Perikanan Budidaya Jakarta, dan 5 (8.93\%) berasal dari Balai Penelitian \& Pengembangan Budidaya Ikan Hias, Depok. Sisanya lain-lain sebanyak $3(5.35 \%)$ artikel. 
Tabel 3. Peneliti yang memberi kontribusi lebih dari satu artikel pada Jurnal Riset Akuakultur Unit berdasarkan Kerja

\begin{tabular}{|c|c|c|c|c|c|c|c|c|}
\hline \multirow{2}{*}{ No } & \multirow{2}{*}{ Unit Kerja } & \multicolumn{5}{|c|}{ Artikel } & \multirow{2}{*}{ Jumlah } & \multirow{2}{*}{ Persentase } \\
\hline & & 2 & 3 & 4 & 5 & 9 & & \\
\hline 1 & $\begin{array}{l}\text { Pusat Penelitian \& Pengembangan } \\
\text { Perikanan Budidaya (P4B) Jakarta }\end{array}$ & 4 & 1 & 1 & 1 & & 7 & 12.50 \\
\hline 2 & $\begin{array}{l}\text { Balai Besar Penelitian \& Pengembangan } \\
\text { Budidaya Laut (BBPPBL) Gondol }\end{array}$ & 9 & 2 & 1 & & & 12 & 21.42 \\
\hline 3 & $\begin{array}{l}\text { Balai Penelitian \& Pengembangan } \\
\text { Budidaya Air Tawar (BPPBAT) Bogor }\end{array}$ & 6 & 3 & 1 & & & 10 & 17.87 \\
\hline 4 & $\begin{array}{l}\text { Balai Penelitian \& Pengembangan } \\
\text { Budidaya Air Payau (BPPBAP) Maros }\end{array}$ & 6 & 3 & 5 & 2 & 1 & 17 & 30.36 \\
\hline 5 & $\begin{array}{l}\text { Balai Penelitian Pemuliaan dan Teknologi } \\
\text { Budidaya Perikanan Air Tawar } \\
\text { (BPPTBPAT) Sukamadi }\end{array}$ & 2 & & & & & 2 & 3.57 \\
\hline 6 & $\begin{array}{l}\text { Balai Penelitian \& Pengembangan } \\
\text { Budidaya Ikan Hias (BPPBIH) Depok }\end{array}$ & 4 & & 1 & & & 5 & 8.93 \\
\hline 7 & Lain-lain & 3 & & & & & 3 & 5.35 \\
\hline & Total & 34 & 9 & 9 & 3 & 1 & 56 & 100 \\
\hline
\end{tabular}

Dari 56 orang penulis memberi kontribusi lebih dari satu artikel, 34 orang penulis memberi kontribus dua artikel yang tersebar disemua unit kerja, 9 orang penulis memberi kontribusi tiga artikel (masing-masing 3 penulis dari Balai Pengelitian dan Pengembangan Budidaya Air Tawar Bogor dan Balai Penelitian \& Pengembangan Budidaya Air Payau Maros, 2 penulis dari Balai Besar Penelitian dan Pengembangan Budidaya Laut Gondol, dan 1 penulis dari Pusat Penelitian dan Pengembangan Perikanan Budidaya Jakarta), 9 orang penulis memberi kotribusi empat artikel (5 penulis dari Balai Penelitian \& Pengembangan Budidaya Air Payau Maros, masing-masing 1 penulis dari Pusat Penelitian dan Pengembangan Perikanan Budidaya Jakarta, Balai Besar Penelitian dan Pengembangan Budidaya Laut Gondol, Balai Penelitian \& Pengembangan Budidaya Air Tawar Bogor, dan Balai Penelitian \& Pengembangan Budidaya Ikan Hias). Sedang 3 penulis yang memberi kontribusi 5 artikel (2 penulis dari Balai Penelitian \& Pengembangan Budidaya Air Payau, Maros dan 1 penulis dari Pusat Penelitian dan Pengembangan Perikanan
Budidaya Jakarta), 1 penulis memberi kontribusi 9 artikel yaitu dari Balai Penelitian \& Pengembangan Budidaya Air Payau Maros.

d. Tingkat Kolaborasi

Kolaborasi dalam kegiatan penelitian menciptakan kesempatan berbagi atau transfer pengetahuan, keahlian dan Teknik tertentu dalam suatu ilmu, pembagian kerja dan pemanfaatan keahlian secara efektif, serta peningkatan produktivitas. Kolaborasi merupakan terjemahan dari kata "collaboration" yang artinya kerjasama. Kolaborasi mencakup semua kegiatan yang ingin dicapai dan mempunyai tujuan serta manfaat yang sama. Kolaborasi terjadi apabila lebih dari satu orang atau lembaga bekerjasama dalam suatu kegiatan penelitian dengan memberikan sumbangan ilmu pengetahuan, tindakan intelektual, ataupun materi.

Untuk menghitung tingkat kolaborasi penulis perlu diketahui terlebih dahulu jumlah penulis yang menulis artikel sendirian (tunggal) dan penulis yang berkolaborasi atau satu artikel ditulis oleh dua penulis atau lebih (penulis ganda). Tingkat kolaborasi penulis Jurnal Riset Akuakultur selama 5 tahun dapat dilihat pada Tabel 4. Dari 225 artikel dengan total penulis 
716 orang, 213 artikel karya penulis ganda dengan jumlah penulis 704 orang, dan 12 artikel karya penulis tunggal. Penulis artikel tunggal tersebut masing-masing 4 artikel dari P4B dan Perguruan Tinggi, serta masing 1 artikel dari Balai Besar Penelitian \& Pengembangan Budidaya Laut Gondol, BPPAT Bogor, BPPBAP Maros, dan BPPTBPAT Sukamandi.

Artikel dengan kolaborasi tiga penulis merupakan ya ng terbanyak, yaitu 82 artikel (36.44\%), disusul dengan kolaborasi dua penulis yaitu 53 artikel (23.56\%) kemudian kolaborasi empat sebanyak 51 artikel (22.67\%). Kolaborasi penulis 5 sebanyak 20 artikel $(8.89 \%)$, sedangkan artikel dengan kolaborasi enam penulis jumlahnya 4 artikel (1.78\%) dan kolaborasi tujuh, delapan dan sembilan sangat kecil yaitu masing-masing 1 artikel (0.44\%). Hal ini berbeda dengan jurnal internasional, yang kolaborasi penulisnya biasa mencapai 16 penulis, seperti pada jurnal DNA Research. pertanian tahun 1996-2005 pada pangkalan data AGRIS di Pusat Perpustakaan dan Penyebaran Teknologi Pertanian, nilai kolaborasi hanya berkisaar antara 0.71-0.80.

\section{Kesimpulan dan Saran}

\section{Kesimpulan}

1. Jurnal Riset Akuakultur memuat 225 artikel yang berasal dari 21 unit kerja, sebagian besar artikel berasal dari lingkup Pusat Penelitian dan Pengembangan Perikanan Budidaya (P4B) yaitu 197 (88.44\%) artikel, sisanya $2(0.89 \%)$ artikel dari Balai Besar Penelitian \& Pengembangan Pengolahan Produk \& Bioteknologi Perikanan, 5 (2.22\%) artikel dari luar BalitbangKP, 2 (0.89\%) artikel dari unit kerja di luar (KKP), dan 19 $(8.44 \%)$ artikel dari delapan perguruan tinggi di Indonesia.

Tabel 4. Kolaborasi Penulis Artikel pada Jurnal Riset Akuakultur 2009-2011

\begin{tabular}{clcccc}
\hline No & \multicolumn{2}{l}{ Kolaborasi Penulis } & Jumlah Artikel & Persentase & Total Penulis \\
\hline 1 & Tunggal & 1 & 12 & 5.33 & 12 \\
2 & Kolaborasi & 2 & 53 & 23.56 & 106 \\
3 & Kolaborasi & 3 & 82 & 36.44 & 246 \\
4 & Kolaborasi & 4 & 51 & 22.67 & 204 \\
5 & Kolaborasi & 5 & 20 & 8.89 & 100 \\
6 & Kolaborasi & 6 & 4 & 1.78 & 24 \\
7 & Kolaborasi & 7 & 1 & 0.44 & 7 \\
8 & Kolaborasi & 8 & 1 & 0.44 & 8 \\
9 & Kolaborasi & 9 & 1 & 0.44 & 9 \\
\hline & & & 225 & 100.00 & 716 \\
\hline
\end{tabular}

Hasil perhitungan tingkat kolaborasi penulis dengan menggunakan rumus tingkat kolaborasi Subramanyan (1983) diperoleh tingkat kolaborasi penulis sebesar 0.94. Data ini menunjukkan bahwa sebagian besar artikel kelautan perikanan pada jurnal riset akuakultur merupakan karya kolaborasi. Tingkat kolaborasi penulis pada jurnal riset akuakultur lebih tinggi dibanding dengan hasil kajian Sutardji (2011) pada Jurnal Penelitian Pertanian Tanaman Pangan tahun 2008-2010 dengan nilai kolaborasi sebesar 0.92. Sedangkan hasil kajian Sormin (2009) terhadap artikel hasil penelitian
2. Produktivitas tertinggi peneliti Lingkup $P 4 B$ diperoleh dari unit kerja $\mathrm{P} 4 \mathrm{~B}$ sendiri dan BPPBAT Bogor yaitu masing-masing 0.30 per tahun, kemudian BPPBAP Maros 0.26 per tahun, BBPPBL Gondol 0.13 per tahun, BPPTBPAT Sukamandi 0.10 per tahun, dan BPPBIH Depok 0.06 per tahun.

3. Penulis pertama yang memberi kontribusi lebih dari satu artikel terbanyak berasal dari BPPBAP Maros yaitu 17 (30.36\%) artikel, disusul BBPPBL Gondol sebanyak 12 (21.43\%) artikel, kemudian BPPBAT Bogor $10(17.87 \%)$ artikel, dari P4B Jakarta 7 (15.63\%) artikel, dan BPPBIH Depok 5 
$(8.93 \%)$ artikel. Sisanya lain-lain sebanyak 3 (5.35\%) artikel.

4. Artikel dengan kolaborasi tiga penulis merupakan yang terbanyak, yaitu 82 artikel (36.44\%), disusul dengan kolaborasi dua penulis yaitu 53 artikel (23.56\%) kemudian kolaborasi empat sebanyak 51 artikel (22.67\%). Kolaborasi penulis 5 sebanyak 20 artikel (8.89\%), sedangkan artikel dengan kolaborasi enam penulis jumlahnya 4 artikel $(1.78 \%)$ dan kolaborasi tujuh, delapan dan sembilan sangat kecil yaitu masing-masing 1 artikel (0.44\%).

Saran

1. Produktivitas peneliti di KKP khususnya lingkup $\mathrm{P} 4 \mathrm{~B}$ perlu ditingkatkan baik melalui peningkatan sumberdaya peneliti, sarana penelitian, sumber-sumber informasi dan maupun sarana pendukung lainnya;

2. Menyediakan media atau wadah yang cukup sebagai sarana untuk publikasi hasil karya ilmiah;

3. Perlu dilakukan pengkajian produktivitas penelitian lebih lanjut, baik ditingkat masingmasing unit kerja KKP atau pun di tingkat KKP sendiri.

\section{Daftar Pustaka}

Blackburn, R.T., C.E. Behymer, and D.E. Hal. 1978. Research notes; correlates of faculty publication. Sociol. Educ. 51: 132-141.

Braun, T., W. Glanzel, and A. Schubert. 1990. Publication productivity; from frequency distribution to scientometric Indicator. J. Inform. Sci. 16: 37-44

Budd. 1995. Productivity of US library and information science faculty: the hayes study revisited. Lib. Quarterly 66(1): 1-20.

Diodato, V. 1994. Dictionary of Bibliometrics. The Harowth Press, Inc., New York.

Kep. Bersama Ka LIPI dan Ka BKN Nomor 3719/D/2004 dan Nomor 60 Tahun 2004
Lakitan, B. Iptek Voice : Produktivitas Peneliti Indonesia. Berita Kegiatan Ristek. Selasa, 6 Maret 2012.

Rufaidah, V.W. Produktivitas publikasi penelitian Badan Litbang Pertanian. Jurnal Perpustakaan Pertanian Vol. 19, Nomor 1, 2010

Salinding, R. 2011. Analisis pengaruh pelatihan terhadap produktivitas kerja karyawan pada PT. Erajaya Swasembada Cabang Makassar. Skripsi. Jurusan Manajemen Fakultas Ekonomi, Universitas Hasanuddin, Makassar.

Sormin, R. 2009. Kajian korelasi antara kolaborasi peneliti dan produktivitas peneliti lingkup Badan Litbang Pertanian. Jurnal Perpustakaan Pertanian 18(1): 1-6.

Subramanyan, K. 1983. Bibliometrics study of research collaboration;review. J. Inform. Sci. 6(1): 33-38.

Sulistyo-Basuki. 1992. Teknik dan Jasa Dokumentasi. Jakarta:Gramedia. 257 hlm.

Sulistyo-Basuki. 2001. Kajian jaringan ilmiah di Indonesia dengan menggunakan analisis subyek dan analisis sitiran. Laporan Final Hibah Bersaing VII/3 Perguruan Tinggi Tahun Anggaran 2000/2001. $37 \mathrm{hlm}$.

Sutrdji, 2012. Produktivitas Publikasi Peneliti Balai Penelitian Tanaman Kacang-kacangan dan Umbi-umbian. J. Perp. Pertanian,Vol. 21 No.1 April 2012: 23-29.

Wahid, N. Kolabomrasi, graf komunikasi, dan produktivitas peneliti dalam penulisan karya ilmiah. Sumber http://pustaka1987.wordpress.com/2010/0 8/25/aplikasi-teori kolaborasigrafkomunikasidan-produktivitas-penelitidalam-penulisan-karya-ilmiah/. 
Zainab, A.N. 2000. Publication productivity, focus on institutional,collaborative and communicational correlates: A review of literature. Malay. J. Libr. Inform. Sci. 5(1): 53-94.

http://Majlis.Fsktm.Um.Edu.My/Downlog.Asp

? Aid=154. [15 Agustus 2008]. 